\title{
Book Review: The Pimping of Prostitution: Abolishing the Sex Work Myth by Julie Bindel
}

Roger Matthews

The University of Kent, r.matthews184@btinternet.com

Follow this and additional works at: https://digitalcommons.uri.edu/dignity

Part of the Civic and Community Engagement Commons, Civil Law Commons, Civil Rights and Discrimination Commons, Community-Based Learning Commons, Community-Based Research Commons, Community Psychology Commons, Criminal Law Commons, Criminology Commons, Domestic and Intimate Partner Violence Commons, Human Rights Law Commons, Law and Economics Commons, Law and Gender Commons, Law and Politics Commons, Law and Psychology Commons, Law and Society Commons, Legal Remedies Commons, Personality and Social Contexts Commons, Sexuality and the Law Commons, and the Social Work Commons

\section{Recommended Citation}

Matthews, Roger (2018) "Book Review: The Pimping of Prostitution: Abolishing the Sex Work Myth by Julie Bindel," Dignity: A Journal of Analysis of Exploitation and Violence: Vol. 3: Iss. 1, Article 2. https://doi.org/10.23860/dignity.2018.03.01.02

This Book Review is brought to you for free and open access by DigitalCommons@URI. It has been accepted for inclusion in Dignity: A Journal of Analysis of Exploitation and Violence by an authorized editor of DigitalCommons@URI.For more information, please contact digitalcommons-group@uri.edu. 


\section{Book Review: The Pimping of Prostitution: Abolishing the Sex Work Myth by Julie Bindel}

\section{Keywords}

prostitution, pimping, myth, sex work, abolition, Nordic model, legalization, decriminalization, sex trafficking

\section{Creative Commons License}

\section{(c) (1) $(9)$}

This work is licensed under a Creative Commons Attribution-Noncommercial-No Derivative Works 4.0 License.

\section{Acknowledgements}

Dignity thanks the following students for their time and expertise in editing this book review: Doriana Magliocchi and Lily Lachapelle, psychology and gender and women's studies major and a minor in Arabic. 


\section{DIGNITY}

Volume 3, Issue 1, Article 2, 2018
A JOURNAL ON

SEXUAL EXPLOITATION

AND VIOLENCE

BOOK REVIEW: THE PIMPING OF PROSTITUTION: ABOLISHING THE SEX WORK MYTH BY JULIE BINDEL LONDON: PALGRAVE MACMILLAN, 2017, AUSTRALIA: SPINIFEX PRESS, 2017

\section{Roger Matthews}

The University of Kent, UK

\section{KEYWORDS}

prostitution, pimping, myth, sex work, abolition, Nordic model, legalization, decriminalization, sex trafficking

$\mathrm{T}$

HIS BOOK HAS TWO MAIN STRANDS. The first strand sets it apart from the existing literature on prostitution and the sex trade inasmuch as it provides a survey of most of the major contributors to this debate from around the world. In this way, the book offers a rare insight into the contours of the contemporary debate and serves as an invaluable resource to those who are trying to familiarize themselves with this highly contested area of inquiry. The second strand involves a tour de force of the main issues. In contrast to the bulk of the literature on prostitution, which emanates from the liberal/libertarian pro-prostitution lobby, this book aims to persuade the reader of the validity of the abolitionist position, which is committed to the eradication of prostitution.

In contrast to the banal assertion that prostitution is the "oldest profession," Bindel argues that prostitution-like other social ills, such as violence, child abuse, and racism-needs to be confronted and ideally eradicated. This assertion may sound utopian, but the reality is that the abolitionist movement has gained considerable ground over the last decade or so. In particular, a number of countries including Sweden, Norway, Finland, Canada, France, and Ireland have adopted the so-called Nordic Model and have passed legislation to outlaw the purchase of sex.

Bindel argues that the liberals and libertarians see themselves as radicals supporting a free market in sex, but in fact, they are simply defending the status quo of male domination and exploitation. Defending the free trade in sexual services provides an invitation to pimps, racketeers, and criminal networks to exploit and abuse the women who get caught up in the sex trade.

Bindel argues that the options of legalization or decriminalization are both deeply flawed. She cites evidence from the Netherlands, where legalization is held to an absolute failure-even on its own terms. The closing down of sections of the "red light" district in Amsterdam is seen as testimony to the failure of legalization. Bindel suggests that full decriminalization, which is often associated with New Zealand, is an equally bankrupt model, since it leads to an increase in trafficking, 
encourages sex tourism, promotes violence against women, and facilitates the overall expansion of the sex trade.

Both legalization and decriminalization tend to create "the invisible man," that normalizes and neutralizes the male buyer. Whereas the Nordic Model places the onus on the male buyer. The normalization of the buyer also tends to be promoted in the academic literature on prostitution, wherein the buyers are depicted as sad, lonely, older men, or as the "guy next door," who is in need of sexual variety. This view of the male client, however, does little to explain the disturbing levels of violence that women involved in prostitution often report, or why prostituted women are twenty times more likely than their "normal" female counterparts to be murdered.

Bindel provides a hard-hitting critique of those male and female academics who act as apologists for the forms of male domination that are intrinsic to the sex trade. For not only do these academics in her view try to defend the indefensible, but some are actually involved in this unseemly business. A major offender in Bindel's view is Dr. John Davies, who she claims has been directly involved not only in promoting the sex trade but also associating with a group of scholars who claim that sex trafficking is a myth and in reality, nothing more than a form of economic migration. These "trafficking deniers" have been influential in playing down the sex trafficking issue and by implication, discrediting many of its victims.

The book contains an impressive level of detail that is frequently based on interviews with those directly involved in the sex trade. The Pimping of Prostitution provides a refreshing contrast to the highly conjectural and half-baked assertions that are prominent in much of the existing literature on prostitution. It is a powerful, provocative, and highly original text, which will no doubt add some impetus to the growing abolitionist movement, and may even encourage the less doctrinaire members of the pro-prostitution group to reflect on their position critically. I believe that this book should be widely recommended and made available to students since it would at least help them to develop a more balanced view of these highlycontested issues.

\section{ACKNOWLEDGMENTS}

Dignity thanks the following students for their time and expertise in editing this book review: Doriana Magliocchi and Lily Lachapelle, psychology and gender and women's studies major and a minor in Arabic.

\section{AUTHOR BIOGRAPHY}

Roger Matthews is professor of criminology, University of Kent, Canterbury, England. He is the author of a number of books and articles on prostitution including Prostitution, Politics and Policy (Routledge, 2008) and is the lead author on Exiting Prostitution: A Study in Female Desistance (Palgrave Macmillan, 2014). He was also the advisor to The All Party Parliamentary Group on Prostitution 2014-2015, and a contributory author of the Parliamentary Report "Shifting the Burden” (2015). 


\section{RECOMMENDED CITATION}

Matthews, Roger. (2018). Book review: The pimping of prostitution: Abolishing the sex work myth. Dignity: A Journal of Sexual Exploitation and Violence. Vol. 3, Issue 1, Article 2. https://doi.org/10.23860/dignity.2018.03.01.02 